\title{
ATATÜRK'ÜN DEMOKRASI DERSLERI (III)
}

\author{
Prof. Dr. Ozer OZANKAYA \\ Siyasal Bilgiler Fakültesi \\ Ögretim Üyesi
}

$\mathrm{Bu}$ inceleme dizisinin ilk ikisinde Atatürk'ün çağdaş toplumun iki temel gerçekliği olan "ulus" ve "demokratik devlet" konularına ilişkin anlayışını kendi kaleminden tanıtmıştım. Bu üçüncü incelemede ise Atatürk'ün "yurttaş hak ve görevleri" konusundaki görüşlerini, özellikle özgürlük kavramını açıklayışını, özgürlüğün başlıca değişik türleri olan bireysel ve toplumsal bzgürlükler konusundaki düşüncelerini yine asıl olarak kendi kaleminden tanıtmaya çalışacağım. Atatürk'ün bu düşüncelerinin, hâlâ insan haklarını gerçekleştirme uğraşı içinde olan günümüz insanlığına -hem de en ileri kesimlerine- yol gösterici değeri açıkça ortaya çıkacaktır kanısındayım.

Atatürk'ün amac1, Türk toplumunda demokratik siyasal kültürü oluşturup geliştirmek idi. Bu amaçla söz konusu 'demokrasi dersleri'ni içeren "Vatandas İçin Medeni Bilgiler" adlı kitabın yalnız orta öğretim kurumlarında bir ders kitabı olarak kalmasını da yeterli görmemiş ve kitabı Başbakan İsmet İnönü'ye tanıtan mektubunda aynen şu isteğini de belirtmiştir :

"Bu kitabın okutulacağı sınıfların yukarısına geçmiş olan öğrencilere de okullarını bitirmeden önce programlara ek olarak okutulmasını çok yararlı bulurum. Bundan başka bu kitapların ülkede yurttaşlara okutulması için tanınms sağlıyacak her önlemin değerli olacağı kanısında bulunuyorum."

Atatürk, 'yurttaş hak ve görevleri' konusuna önce 'devletin yurttaşlara karşı görevleri” konusuyla girmekte, sonra da "özgürlük" kavramını tarihçesiyle başlıyarak açıklamakta, başlıca özgürlük tür lerini incelemekte, özgürlük için hoşgörünün ne denli gerekli oldu-

* "Devletin yurttaşlara karşı görevleri" konusundaki bölümü, "Atatürk'ün Düşüncesinde Ekonomi-Demokrasi İlişkileri" (Prof. Dr. İbrahim Yasa'ya Armağan, S.B.F. Yayını, 1983, s. 369-380) başlıkh incelemede yayınlamış bulunuyorum. 
ğuna da özel bir yer ayırmaktadır. Bir de "bireysel ve toplumsal özgürlükler' ayrımını yapmakla, devletin yurttaşa karşı görevlerine de ön planda ve geniş yer vermekle, günümüzün en ileri insan hakları anlayışında anlatımını bulan 'pozitif özgürlükler - negatif özgürlükler' ayrımına temel olan çağdas toplum gerçekliğini öngörmüş bulunduğunu ortaya koymaktadır.

\section{ATATÜRK'ÜN YURTTAŞ HAK VE ÖZGÜRLÜKLERI KONUSUNDAKİ GÖRÜŞLERİ}

Atatürk'ün bu konudaki görüşlerini aşağıdaki sıra içinde suna. cağım :

I. Özgürlük kavramı ve tarihsel gelişmesi
a) Bireysel özgürlük kavramı
b) Toplumsal ve uygar insan özgürlüğü kavramı

II. Özgürlüğün değişik biçimleri

1. Bireyin maddi çlkarlarına ilişkin özgürlükleri :
a) Kişisel özgürlük
b) Konut dokunulmazlığı
c) Bireysel mülkiyet
c) Ticaret, çalışma ve zenaat özgürlüğü

2. Bireyin düşünce yaşamındaki özgürlük haklàrı :
a) İnanç özgürlüğü
c) Toplanma özgürlüğü, kamuoyu ve örgütlenişi
c) Basın özgürlüğü
.̧) Dernek kurma özgürlüğü

3. Duyurma ve Şikâyet hakkı

4. Özgürlüğün korunması ve yaptırımları

III. Hoşgörü

\section{Atatürk'ün Düşüncesinde Özgürlük Kavramı ve Tarihsel Gelişimi}

"Özgürlük, insanın düşündüğünü ve dilediğini kesinlikle yapabilmesidir. 
Bu tanım, özgürlük sözcüğünün en geniş anlamıdır. İnsanlar bu anlamda özgürlüğe hiçbir zaman sahip olmamışlardır ve olamazlar. Çünkü bilindiği üzere insan doğanın yaratığıdır. Doğanın kendisi bile kesinlikle özgür değildir; evrenin yasalarına bağımlıdır. Bu nedenle insan ilk önce doğa içinde, doğanın yasalarına, koşullarına, nedenlerine, etkenlerine bağlıdır. Örneğin dünyaya gelmek ya da gelmemek insanın elinde olmamıştır ve değildir. Insan dünyaya geldiktan sonra da, daha ilk andan doğanın ve birçok yaratıkların karşısında savunmasızdır. Korunmaya, beslenmeye, bakulmaya, büyütūlmeye muhtaçtır.

İlkel insanların doğanın her şeyinden, gök gürültüsünden, karanlıktan, taşan bir urmaktan ve yurtıcl hayvanlardan, dahası biribirlerinden korktuklarnn biliyoruz. İk duygu ve düşüncesi korku olan insanın her düşünce ve dileğini kesin biçimde yapmaya kalkışmış olması düşünülemez.

İlkel insan kümelerinde ata korkusu ve en sonunda büyük oymak ve topluluklarda ata korkusu yerine geçen Tanrı korkusu, insanların kafalarında ve davranışlarında sayısız yasaklar yaratıştır. Yasaklar ve boş sözler üzerine kurulan birçok gelenekler ve görenekler, insanları düşünce ve davranışta çok bağlamıştır. Öylesine ki kişisel düşünce ve davranma özgürlügü gibi bir hak kavramı bilinmemiştir.

Toplulukların başına geçebilen adamlar, topluluğu tanrı adına yönetirlerdi. Her türlü hak ve yetki onlarda idi. Bireyin hakkı, özgürlüğü söz konusu değildi.

Buraya kadarki görüşlerimizi şöyle bir sonuca bağllyabiliriz : insan önce doğanın tutsağı idi; sonra buna gökten güç ve yetki alan bir takım adamlara tutsak olmak eklendi. Insan toplumları büyüdükçe ve devlet durumuna geldikçe, bireyler üzerindeki ağırlık o kadar çoğaldı. Devletin başında bulunan adamın hakkı sınırsız, kısıtlamasız, koşulsuz saltık bir güç olarak görülüyordu. Devletin biçimi imparatorluk ya da cumhuriyet olsun, bunun önemi azdı; bireyin kişisel bir hakkı yoktu. Eski zamanlarda insanların yapabildikleri uygarlıklarinin en yüksek dönemlerinde, durum böyleydi. Bireyin hakkı, buyurganın yararına olarak, tanrısal ha kiçindeydi. Bu hakka dayanarak buyurgan (hükümdar), uyruklarının özgürlüğüune istediği gibi el koyabilirdi; bu, bireyin hakkına saldın sayılmazdı.

Buyurganın gücü için dinlerden çıkan sınırdan başka bir sınır tanınmıyordu. Buyurganın yapmaması gereken şey, tanrının yasakladığı şey olacaktı. 
İnsanlar düşünsel gelişmede ilerledikçe, kendi kökenlerini daha açlk düşünmeğe başladılar; yavaş yavaş onun büyüklüğünü daha iyi anlamaya ve değerini bilmeğe güçleri yetti.

Doğanın herşeyden büyük ve her şey olduğu anlaşıldıkça, doğanın çocuğu olan insan kendinin de büyüklüğünü ve onurunu anlamağa başlad.

İste insanlar bu anlayış düzeyine yükseldikten sonradır ki, "doğanın insanda yarattığı bütün yetenekler, etkinliklerini özgürce yapmalı ve özgürce gelişmelidirler; bu gereklilik doğaldır; doğanın verdiği haktır" düşüncesine vardılar.

Artik bundan sonra birey ile buyurgan ve devlet arasinda hak davasi ve hak mücadelesi başlar. Bu mücadele devletlerin ic gelisimlerinin tarihidir.

Onaltıncı yüzyılda ileri sürülen düşünceler şöyle idi : Buyurgan buyruklarıyla, yasalarıyla tanrısal hakkı olduğu gibi doğal hakkı da bozamaz. Doğal hak da tanrı tarafından konulmuş gibi kabul edilmelidir. Çıkış noktası olarak bu düşünce kaldıkça, buyurgan gücünün sınırının temelini tanrısallık düşüncesi ve tanrısal istenç oluşturdu. Çünkü doğal haklar da aynı temele bağlanmıştı. Buyurgan bu sınıra uyuyor idiyse, bu uymayı dinsel bir görev saydığındand, yoksa bireyin buyurgana karşı istekte bulunabileceği hiç bir hak tanınmış değildi. Bireysel haklar görüşü, doğal hak düşüncesi, tanrısallık düşünsel temelinden, yani gökten koparılarak yeryüzüne indirildikten sonra meydana çikabilmiştir.

Birey hakları görüşünün temeli şöyle kuruldu : Her türlü hakkun kökeni bireydir. Çünkü gerçeklikte özgür ve sorumlu ,olan yaratık yalnız insandır.

Buna göre bireyin yalnız doğal hak ve ahlâki sorumluluk ile s1nırlı olan saltık bağımsızlığı, bütün uygar örgütlenişlerden önce gelen ilk durum olarak, çıkıs noktası gibi kabul olunuyor. Ama öte yandan insanların toplumsal ve siyasal örgütler durumunda bulunması da doğal ve gereklidir.

Bu örgütlenişler ise, bir bölümüyle zorunlu, kaçınılmaz yasalar hükümlerine göre evrimleşir. Bu kaçınılmazlığın varlığı oranında ve zekânın bu kaçınılmazlığın akışını ve yönünü değerlendirebilmesi oranında, insanların özgürlük ve istençleri bu kaçınılmazlığa boyun eğmek zorunluğundadır. İnsanlar hareketlerini bu kaçınılmazlığın akıs ve yönüne uydurmak zorundadırlar. Bu zorunluluk durumu, 
gerçekte, kaçınılması olanaksız bir sonucu daha yetkin ve daha uyumlu yapmaktadır. Doğanın ve tarihin ürünü olan bir ulusun bireyleri her zaman bu gerçekle karşı karşıya bulunur ve ona saygı gösterir. Böyle bir ulusun kurduğu devletin de temeli ve amacı bireysel hak olur.

Bireyin birinci hakkı, doğal yeteneklerini özgürce geliştirebilmesidir. Bu gelişimi sağlamak için en iyi araç ise, bireye, başłasının eş hakkına zarar vermeksizin, tehlike ve zarar kendisine ait olmak üzere, kendi kendini istediği gibi yöneltip yönetmesine müsaade etmektir.

İşte bu özgür gelişimi sağlamak, bireysel hakların oluşturduğu türlü özgürlüklerin bütün amacıdır. Bu haklara saygı göstermiyen siyasal toplum temel görevini aksatmış olur ve devlet varlığının nedenini ve anlaminı yitirir.

\section{Çağdaş Demokraside Durum}

Çağdaş demokraside bireysel özgürlükler özel bir değer ve önem kazanmıştır; artık birey özgürlüklerine devletin ve hiç kimsenin karışması söz konusu değildir. Ancak böylesine yüksek ve değerli olan birey özgürlüğünün uygar ve demokrat bir ulusta neyi anlattığı, özgürlük sözcüğünün saltık olarak düşünülebilen anlamıyla anlaşılamaz. Sözkonusu olan özgürlük, toplumsal ve uygar insan özgürlüğüdür. $\mathrm{Bu}$ nedenle bireysel özgürlüğü düşünürken, her bireyin ve en sonunda bütün ulusun ortak yararı ve devlet varlığı gözönünde bulundurulmak gerekir. Anlaşllıyor ki birey özgürlüğü saltık olamaz. Başkasının hak ve özgürlüğü ve ulusun ortak yararı birey özgürlüğünü sinırlar. Bireysel özgürlüğü sinırlama devletin de düpedüz temeli ve görevidir. Çünkü devlet birey özgürlüğünü sağlyyan bir örgüt olmakla birlikte, aynı zamanda bütün özel etkinlikleri genel ve ulusal amaçlar için birleştirmekle yükümlüdür. "Özgürlük başkasına zararlı olmuyacak her türlü işlemlerde bulunmaktır"* denildiğinde yurttaş özgürlüğünün, yalnız bunun amaç olduğu, devletin bu amacı sağlamak için bir araç sayıldığı söylenmiş olur. Ama bu araçtır ki ulusun genel yarar ve amacını koruyacaktır. Öyleyse bireysel özgürlüğe sınır olarak "başkalarının özgürlük sınırın" ** gösterirken, bireysel özgürlüğün ulusun genel yararının gerektirdiği ölçüden daha çok sınırlandırılmıyacağı kabul edilmiş oluyor. Bu düşünce basittir; ama uygulaması çok güçtür. Çünkü bireysel özgürlü-

* Anayasa, Md. 68 .

* Anayasa, Md. 68. 
ğüin ölçüsü, devlet etkinliklerini zayıflığa düşürmemelidir. Devletsiz bir toplum ya da zayff bir devlet yaşamının sonucu, herkesin herkese karşı mücadelesidir. IBu mücadele çoğunluğun özgürlüğünü boğmuyacak biçimde değişt rilmek gerekir.

$\mathrm{Bu}$ değiştirme işi bireyin sorumluluğuna, girişimine ve gelişimine zarar verecek ölçüye götürülmemelidir.

Yurttaşların girişim ve sorumluluk duygularn ne kadar gelişirse devlet için o kadar iy idir.

Birey özgürlüğünür ne kadarından vazgeçilmesi gerekeceği, içinde bulunulan zamánz ve ülkeye göre değişir. Olağan dışı zamanlar, olağan dışı önlemler gerektirebilir. Bir de özgürlüğün kötüye kullanılması, özgürlüğüı geçici, ama geniş ölçüde sınırlandırılmasını gerektirebilir. Bütüı bu önlemleri ve sinırlamalar tanımak gereği, devlet düşünce ve kavramını anlatır. Bu hususlardaki önlemlerin ağırlığını ve sınırlarının genişliğini ölçmek büyük bir sanattır. Devlet sanatı işte buduj. Bu sạattaki başarının ölçüsü, özgürlüklerin sınırlarını çizen yası̇da görülebilir.

Çünkü "bu sınır ancak yasa yoluyla saptanıp belirlenir". Her halde, yurttaşlarin genel özgürlük ve mutluluğu için bireylerden, ancak devlet için zorunlu olan bir bölüm özgürlüklerinin bırakılması istenebilir.

Türk ulusunun tar hini gözönüne getirelim; hemen daha düne değin'altında ezildiği baskı yönetimi, tutsaklık ve zulmün kara, kanl pençesini duyar gibi olmamak olanaksızdır.

Türk, baskı ve tutıaklık zincirlerini parçallyabilmek için iç ve dış düşmanlar karşısında yaşamını ortaya attı; çok kanlı ve teblikeli mücadelelere girdi; sayısız özverilere katlandı; başardı, ancak ondan sonra özgürlüğüne sah.ip oldu. Bu nedenle özgürlük Türkün yaşamidir.

Artık Türkiye'de "her Türk özgür doğar, özgür yaşar"*.

Türkün bugünkü ulusal ve siyasal eğitimi ve yüksek değeri, onun amacinı ve durumunu saptamıştır.

\section{Sonuç :}

Türkler demokrat, özgür ve sorumlu yurttaşlardır. Türk Cumhuriyetinin kurucuları ve sahipleri doğrudan doğruya kendileridir.

- Anayasa, Md. 68. 
Türk, bireysel özgürlüğündén ve yararlarından Anayasa'da belirlenen kadarını cumhuriyete burakmıştır. Cumhuriyet, bireyin ona blraktığı bu bölüm özgürlüğü, bireyin ve Türk ulusunun içerde özgürlüğünü ve dışarıya karşı bağımsızlığını güvence altına almak için kullanır.

\section{1. "ÖZGÜRLÜĞÜN DEĞISŞIK BiÇIMLERI" Konusundia Atatürk'ün Görüşleri}

Bir ulusun kültürü yükseldikçe bireysel özgürlüğün uygulama alanları genişler ve çoğalır. Örneğin ilkel bir insanla uygar bir insanın özgürlük gereksinimleri aynı değildir. İnsan toplumlarn uygarlaştıkça türlü biçimde, biribirinden ayrı ve bağımsız bireysel özgürlükler ortaya çıar. Bu özgürlükler nitelik ve doğalarına göre iki kümeye aymlir :

A. Bireyin maddi çıkarlarının karşıliğı olan özgürlükler

B. Bireyin düşünsel yaşamındaki özgürlük haklarn

A. Birinci küme içinde sayabileceğimiz özgürlüklerin başlıcalan şunlardır :

1. Kişisel özgürlük

2. Konut dokunulmazlığı (konutun saldırıya karşı dokunulmazluği)

3. Bireysel mülkiyet

4. Ticaret, çalışma ve zenaat özgürlükleri

1. Kişisel özgürlük : Sözcüğün dar anlamıyla kişisel özgürlüktür. Yani özgürce gitmek, gelmek, ulusal topraklarda kalmak ya da oradan çlkmak hakkına sahip olmaktır (gezi ve oturma hak ve özgürlüğü) . Bununla birlikte gönlünce (keyfi) tutuklamalardan, gönlünce hapisten, gönlünce cezadan korunmuş olmak güvencesidir. Kişinin özgürlüğü insanlığın zorunlu gereğidir.

2. Konut dokunulmazlığı, konutun saldınya karşı dokunulmazlığıdır. Bu hak kişisel güvenliğin başlangıcı ve devamıdır. Insan evinin sahibidir ve oraya ancak istediğini sokar. Bir insanın evine hükümetin karışması, yalnız yasanın belirlediği durumlarda ve biçimde olabilir.

3. Bireysel mülkiyet: Bir insanın emeği ürünü olan her şeye sahip olması, devletin karışamıyacağı yüksek haklardandır. İnsan 
namuslu bir yoldan sahibi olduğu mal ve mülkünü dilediği gibi kullanır, satabilir, satmıyabilir, istediğine verebilir, onlan dilediği gibi kullanabilir. Eski zamanlarda böyle değildi, tersi idi; insanları olurları bulunmadığı halde, aileleriyle, oturdukları yerle birlikte satabilirlerdi.

Bireysel mülkiyet hakkını sınırlıyan tek şey, genel yararlar için kamulaştırmadır. Bununla birlikte hükümetin, belediyelerin, yerel yönetimlerin ne gibi gerek ve' zorunluluklarla ve hangi yol ve biçimle kamulaştırabilecekleri, kamulaştırma yasalarıyla belirlenmiştir.

Düşünce ve kalem ürünü olan her yapıt da sahibinin hakkıdır. Bu hak "Yazar Hakkı Yasası" ile güvenceye alınmıştır.

4. Ticaret, çallşma ve zenaat özgürlüğü : Insan yaşamını kazanmak için istediği işte, meslekte, ve sanatta çalışabilir, bu bakımdan özgürdür. Ancak bu özgürlük kamunun iyiliği için, akla uygun olarak, bir takım yasal sınırlamalar ve koşullara bağlıdır. Örneğin bir sütçü, bir. ekmekçi, bir takım sağlık kurallarına uymak zorundadır.

Bir tüccar, yabancı ülkelerden getirdiği malları gümrük vermeden ülkeye sokamaz.

Herkes ülkede istediği gibi öğretmenlik, avukatlık, doktorluk yapamaz; bunun için yasa gereğince bir takım niteliklere sahip olması gerekir.

Bunlardan başka devletin siyasal amaçla ya da kamunun yararı ve güvenliği amacıyla tekel altında bulundurduğu işleri başkaları yapamaz. İçki ve tütün gibi.

Bütün bu engellerle birlikte, insan için her. zaman yeterli bir çalısma ve biriktirme özgürlüğü vardır.

B. İkinci kümeye giren özgürlükler daha çok, doğrudan doğruya bireyin düşünsel yaşamındaki özgürlük haklarıdır. Bunlardan :

1. Birincisi İnanç özgürlüğüdür : her birey istediğini düşünmek, istediğine inanmak, kendine özel siyasal bir düşünceye malik olmak, bağlı olduğu bir dinin gereklerini yapmak ya da yapmamak hak ve özgürlüğüne maliktir. Kimsenin düşüncesine ve vicdanına eğemen olunamaz.

İnanç özgürlüğü saltık, saldırılmaz, bireyin doğal haklarının en önemlilerinden tanınmalidır.

Uygarlığın geri olduğu. bilgisizlik dönemlerinde, düşünce ve inanç özgürlüğü boyunduruk ve baskı altında idi. İhsanlık bundan 
çok zarar görmüştür. Özellikle din koruyuculuğu kılığına bürünenlerin gerçeği düşünebilenler, söylüyebilenler hakkında uygun gördükleri ezinç ve işkenceler, insanlık tarihinde her zaman kirli, acıklı olaylar olarak kalacaktır.

Türkiye Cumhuriyetinde her ergin dinini seçmekte özgür olduğu gibi, belli bir dinin törenleri de özgürdür; yani dinsel tören özgürlügü dokunulmazdır. Doğal olarak dinsel törenler güvenlik ve genel töreye aykırı olamaz, siyasal gösteri biçiminde de yapılamaz. Geçmişte çok görülmüş olan bu gibi durumlara artık Türkiye Cumhuriyeti hiç katlanamaz.

Bir de Türkiye Cumhuriyeti içinde tüm tekkeler ve zaviyeler ve türbeler yasayla kapatılmışlardır. Tarikatler kaldırılmıştır. Şeyhlik, dervişlik, çelebilik, halifelik, falcılık, büyücülük, türbecilik vb. yasaktır. Çünkü bunlar gericilik kaynakları ve bilgisizlik damgalarıdır. Türk ulusu böyle kurumlara ve onların üyelerine katlanamazdı ve katlanmadı.

Laiklik : Türkiye Cumhuriyeti'nin resmi dini yoktur. Devlet yönetiminde bütün yasalar, düzenlemeler bilimin çağdaş uygarlığa sağladığı ilke ve biçimlere, dünya gereksinimlerine göre yapllır ve uygulanır. Din anlayışı vicdan işi olduğundan, Cumhuriyet din düşüncelerini devlet ve dünya işlerinden ve siyasetten ayrı tutmayı ulusumuzun çağdaş ilerlemesinde başlıca başarı etkeni görür.*

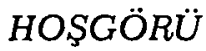

Türkiye'de hiçbir kimse düşüncelerini zorla başkalarına kabul ettirmeğe kalkışamaz ve böyle bir şeye müsaade edilemez. Artık içtenlikli dindarlar, derin inanç sahipleri özgürlüğün gereklerini öğrenmiş görünüyorlar. Bütün bunlarla birlikte, din özgürlüğüne, genellikle vicdan özgürlüğüne karşı hoşgörü (anlayışlllı) oluşmuş mudur?

Bunu anlyyabilmek için hoşgörünün ne olduğunu inceliyelim; çünkü bu sözcüğün belirttiği anlamı, düşünüş biçimini herkes ken-

- Bu paragraf Atatürk'ün Medeni Bilgiler ve Mustafa Kemal Atatürk'ün El Yazıları, (Türk Tarih Kurumu Yayını, 1969) adlı kitaptaki el yazısı fotokopilerinde bulunmamaktadır. Ancak Sayın Prof. Afetinan kitabın önsözünde aynen şunu yazıyor: "Bu kitap benim ismimle çıkmış olmasına rağmen, Atatürk'ün düşūnceleri ve telkinlerinden mülhem olduğunu ve üslubun tamamen kendisine ait olduğunu tarihi hakikatleri belirtmek bakımından bana düşen bir ödev telakki ediyorum." (s.7). 
dine göre anlamağa çok eğilimlidir. Din özgürlüğünü bir hak saym1yan gerçekten kalmadı mı?

Vicdan özgürlüğünün ruhun, Tanrının yüce etki gücü altında, dinsel yaşamı yönetme.k için malik olduğu haktan başka bir şey olmadığını bellemiş olanlar acaba bugün nasil düşünüyorlar? Bu gibiler kendisi gibi düşünmüyenlere içlerinden kızmıyorlar mı?

Bu saydığımız anlayışta bulunduğu olası görülen kimselere, özgür düşünceliler, acaba bir üzüntü duyarak, acımayla bakmıyorlar $\mathrm{ml}$ ?

Bu sayıdığımız gibi değişik inanışlı kimseler birbirlerine kin, tiksinti besliyorlarsa, biribirlerini aşağı görüyorlarsa, hatta biribirlerine yalnızca acıyorlarsa, bu gibi kimselerde hoşgörü yoktur; bunlar hoşgörüsüzdürler.

Hoşgörü o kimsede vardır ki, yurttaşının ya da herhangi bir insanın vicdani ínanışlarına karşı hiçbir kin duymaz; tersine, saygı gösterir. Hiç olmazsa başkalarının, kendininkine uymuyan inanışlarinı bilmemezlikten, duymamazlıktan gelir.

Hoşgörü budur. Ama gerçeği söylemek gerekirse diyebiliriz ki, özgürlüğü özgürlük için sevenler, hoşgörü sözcüğünün ne demek olduğunu anlıyanlar bütün dünyada pek azdır. Her yerde genel olajak yürürlükte olan bağnazlıktır. Her yerde görülebilen banş durumunun temeli, bağnazlık ile özgür düşüncenin biribirine karşı kin ve tiksintisi üstündedir; temelin devrilmemesi, kin ve tiksinti tabanındaki dengeyi tutan artık güçten dolayıdır.

Bu söylediklerimizden şu sonuç çıkar ki, aramızda özgürlük engelleyicilerinin kalktığına, bizim gibi düşünen ve duyanlarla birlikte yaşadığımıza inanmak güçtür. Öyleyse görülen, hoşgörü değil, zayıflığın güçsüz bıraktığı bağnazlıktır.

Kuşkusuz düşüncelerin, inanışların başka başka olmasından yakınmamak gerekir. Çünkü, bütün düşünceler ve inançlar bir noktada birleşecek olursa, bu hareketsizlik belirtisidir, ölüm işaretidir. Öyle bir durum kuşkusuz istenmez. Bunun içindir ki gerçek özgürlükseverler hoşgörünün genel bir huy olmasını dilerler.. Ama, hatta iyiniyetle bile olsa, bağnazlık yanlışlarına karşı dikkatli olmaktan vazgeçemezler. Çünkü iyiniyetle hiçbir zaman, hiçbir şeyi onaramamışlardır. Insanların ruhun esenliği için yakıldıklarını biliyoruz. Herhalde bunu yapan engizisyon papazları, iyiniyetlerinden ve iyi is yaptıklamndan sözederlerdi; belki de gerçekten bu sözlerinde içtenlikli idiler. Ama bir ahmaklığı ya da bir hainliği iyi bir iş kalıbına 
uydurmak güç değildir; en sonunda bu bir ad değiştirmek sorunudur.

İşte bu nedenledir ki hoşgörmekliği aldırmamazlık ölçüsüne götürmemek önemlidir.

Gerçi özgür olmak herkesin hakkıdır ve bunun için gerçek özgürlükçüler, özgürlükçü olmuyanlara karşı da geniş davranılmasını isterler. Ama bunların hiçbir zaman elleri, ayakları bağlı olarak kurbanlık koyun durumuna razı olacakları hiç kabul olunmamalıdır.

Unutmamalıdır ki kimi insanlar geleceği geçmişin arasından görmekte diretirler. Bunlar, ilgimizi kestiğimiz geleneklere bağlılığın kesinlikle yeniden sağlanmasını isterler. Bu gibi insanlar kendi inandikları gibi inanmiyan kimseleri istedikleri gibi ezemezlerse, kendilerini cenderedeymiş gibi duyarlar.

Herhalde hoşgörünün istenildiği gibi yaygınlaşması, huy durumuna gelmesi, düşünce eğitiminin yüksek olmasına bağlıdır.

2. Toplanma özgürlüğü ve 3. Basin Özgürlüğü : Bu iki özgürlük aynı ilkeden çıkar. O ilke, insanların düşüncelerini özgürce söylemek ve yaymak hakkıdır.

Yurttaşlar kendi öğrenim ve eğitimleri için ve kamunun yararları noktasından, düşünce alış-verişi yapmalıdırlar. Düşündüklerini istedikleri gibi söylüyebilmelidirler.

En büyük gerçekler ve anlayş̧lar düşüncelerin özgürce ortaya konması ve karşılıklı alınıp verilmesi ile ortaya çıkar ve yükselir.

Toplanma, insanların birlikte düşünüp konuşmak ya da birinin sözlerini dinlemek amacıyla geçici olarak biraraya gelmeleridir.

Toplanma özgürlüğü anayasımız gereğince bireylerin doğal haklarındandır, ama genel toplantılar yasası çerçevesi içinde ortaya çıkar. Çünkü güvenliği ve toplumsal ve siyasal düzeni korumakla yükümlü olan hükümetin gerekli önlemleri alabilmesi için, toplantının günü ve yeri hakkında, zamanında usulüne göre haberli kulınması gerekir.

Toplantı, insanların bir şeyi birlikte görmek için toplaşmalarından ya da insanların ortaklaşa hareket için sürekli olarak birleşmeleri durumundan ayırt edilmelidir.

Toplantı, adla ve kişisel bir çağrı üzerine olan özel toplanma da değildir. Ülkenin dirlik ve düzenini bozacak biçimde ve yerlerde toplanmak, doğal olarak yasaktır. 
Toplanma özgürlüğü, basın özgürlüğünden eșkidir. Ama basın özgürlüğü, basımevinin ve gazeteciliğin ilerlemesi yardimıyla daha büyük bir önem kazanmıştır.

Basın özgürlüğü, yurttaşların gündelik ya da vakit vakit çıkan gazetelere, dergilere yazacağı yazılar ya da yapacağı resimler aracılığıyla ve yayınlıyacağı kitaplarla düşüncesini özgürce yaymasıdır. Tiyatro, sinema ve gramofon, radyo, telgraf da düşüncelerin yayımlanarak yaygınlaştırılması için çok önemli ve etkin araçlardır. Bir insanın.herhangi bir yerde söylediği sözler orada bulunanlarla sinirlı kalır, etkisi anllk ve sinırlıdır. Ama bu sözler radyo ile söylenirse bütün dünya işitebilir. Tèlgraf da düşüncelerin yayımlanmasında en hızlı araçtır. Ama söz bir gramofon plağına geçerse, özellikle bir gazeteye, bir kitaba geçerse, düşünce saptanmış olur, bütün dünyada okunur; doğal olarak gelecek kuşaklara geçer. Herhangi bir levhaya kazınan resim ve yazlar, bunun gibi yapllan heykeller de simgeledikleri düşünceleri yaşatan yapıtlardur.

Türlü araçlarla saptanan ve hızla yayımlanan düşünceler, bütün insanlığın ilerlemesine ve tarihe büyük hizmette bulunur.

\section{Kamuoyu}

Ulusal eğemenlik ilkesine dayalı temsili bir hükümette kamuoyu büyük bir yer tutar. Basin ve toplanma özgürlükleri olmadan ve kamuya ilişkin işler hakkında geniş bir eleştiri alanı bırakılmadan, kamuoyu görevini yerine getiremez. Ulusal eğemenlik ve temsili hükümet düşüncesinin yayılması ve yükselmesi, ancak kamuoyunun etkinliği ile olanaklıdır.

Hükümetin düşüncesi, ülkenin düşüncesini temsil etmelidir. Hükümet ülkenin düşüncesini anlıyabilmek için, bu düşüncenin belirmesine yol açan araçlara malik olmalıdır. Gerçi hükümet seçim zamanlarında ulusun düşüncelerini öğrenir; seçilen meclisler de ulusun düşüncesini temsil ederler. Ama seçim zamanları ulusun belirttiğgi düşünceler, olduğu gibi kalmaz. Bu nedenle meclislerin bu düsünceleri temsil edebilmesi çok zaman sürmez. Kamuoyu ulusun içinden taşan bir değişken düşünceler denizidir. O denizde türlü akımlar, türlü tartışma dalgaları ortaya çıarır. Kamuoyu ruhsal bir dünyadır. Orada akışan düşünce mücadelesi, dikkatli gözlerden gizli kalmaz. Eski demokrasilerde bu düşünce mücadelesi bütün yurttaşların hergün bir arada toplanarak oluşturdukları toplantılarda gerçekleşiyordu. Bugün yurttaşların sayıca çokluğu ve uygar yaşamın yurttaşlara yüklediği günlük işler, onların maddi olarak ve hergün bir arada toplanmalarına olanak bırakmamıştır. 
Bu nedenle kamuoyu düşünsel bir dünya olmuştur ki, bu dünyada kamuya değgin işlerin eleştirisi şu nitelikleri gösterir :

a) Eleştiri ve tartışma bütünüyle özgürdür. Bu özgürlük herkesçe, hiç kimsenin etkisi olmadan, kendi kendine kullanılır. Hükümeti ve Meclisi dikkatli bulunduran eleştiri özgürlüğüdür.

b) Kamuoyunun eleştiri özgürlüğü, başlıca birçok yayın ile olur.

Yayın, yolsuzlukları önler ve hükümet araçlarını, görevlerini doğru yapmak zorunda bırakır. Yayın en etkili denetim araçlanndandır. Bu noktada, eleştirinin kolay, ama yapmánın güç olduğu gerçeği unutulmamak gerekir. Onun için :

c) Kamunun iyiliği düşüncesi, her türlü eleştirilere ve tartışmalara her zaman üstün ve temel tutulmalıdır. Savunulan düşünceler, kamunun iyiliği adına ortaya atılmalıdır. Bu düşünce çıkıs noktası olunca, eleştiri ve tartışma devletin de iyiliği adına yapılmış ve yurttaşların toplumsal ve siyasal eğitimlerini yükseltmeğe hizmet etmiş olur.

d) Kamuya ilişkin işleri eleştirme özgürlüğü, hükümet ile ulus arasında bir anlaşma ortamı oluşturur. Hükümet yayın yoluyla kamuoyunu anlar ve yeri geldiğinde gerekli olan belgelerle onu aydınlatır. Hükümetin ulusu ve ulusun hükümeti anlaması, bunların tek bir varlık olmalarını ve kalmalarını sağlar.

\section{Kamuoyunun Kendikendine Örgütlenmesi}

Hükümet tutum ve davranışını düzenlemek için kamuoyuna önem verince, kamuoyu örgütlenir. Kamuoyunun her zaman yararlanılabilecek, hazır bir durumda bulunabilmesi, onun bir örgütünün bulunmasıyla olanaklıdır. Bu örgüt, özgür eleştiri ve tartışma alanıdır. Bu alan hep açı olmalı ve hep değişik düşüncelerle beslenmelidir. $\mathrm{Bu}$ ise basının çabası ve kamu yararının hergün yeniden yeniye tartışlmasıyla olur. Kamuoyunun yürürlükte olduğu bir ülkede gazeteler yayınlanmasa, halk şaşkın ve çılgın bir duruma gelir. Sözünü ettiğimiz bu düşünce örgütünde, şu özellikler görülür :

a) Düşünce örgütü, bir azınlığın ya da bir takım seçkin insanların ürünüdür. Kuşkusuz halk yığınları bu örgüte katılır. Ama başka şeylerde olduğu gibi bunda da halk yığınlarının payı etkin değildir. Gerçi halk yayınlar yansıtır, düşüncelere yandaş toplar, ama düşünceleri ortaya atan ve yaymlarn merkezlerini oluşturan halk değildir. 
b) Çağdaş düşünce örgütünde, gerçekte iki seçme kesimin etkinliği vardır. Bu sinfflardan biri, basın girişimlerini ortaya koyan ve jönetenlerdir.

Basın, düşünceleri ortaya atmak ve yayınlamak için gerekli olan araçlardır. Siyasal düşünceleri de üreten basındır. Basın girişimleri, gazeteler, dergiler ve kitap basimı ile olur.

Basının siyasal düşünceler üretmedeki payı; daha çok başka niteliktedir. Çünkü siyasal düşünceleri ortaya atan, her zaman siyasal kümeler ve kesimler gibi düşünce dernekleridir. Yoksa halk yığınlan içinde, kendiliğinden ortaya çıkmaz.

c) İyice bilinmek gerekir $\mathrm{ki}$ gazeteler okul kitapları değildir. Aşağı insanların para ile yaptırdıkları basın mücadeleleri vardır. En bayağı yalanları yaymada basının kullanıldığı olmuştur. Basın ve düşünce özgürlüğünün karşılaştığı başka tehlikeler de vardır. Basının ve dahası düşünce derneklerinin, ulusal hükümetin etkisinden kurtularak siyasal ya da iktisadi gizli amaçlara araç olmasindan korkulur. Basının para ile satın alınabilmesi, uluslararası yüksek para dünyasinın basın üzerinde gizli etkisi ya da yalnızca yabancı devletlerin örtülü ödeneklerinin etkisi, işte bunların kamuoyunu aldatıp yanıltmasından gerçekten korkulur. Ama özgürlükten çlkacak bu kötülükler hiç de çaresiz değildir. Önce basın özgürlüğüne meşru bir sinır çizilir. İkinci olarak gazeteler özel bir örgüt kurarak, bununla kendi üzerlerinde ahlaki bir etkide bulunurlar. İlk zamanlarda bir kazanç işinden başka bir şey olmayan gazetecilik, toplumsal bir kurum durumuna gelebilir. Bundan başka halkın düşünsel yo siyasal eğitimi de bir güvencedir. Halk birçok gazeteleri okumağa ve onları biribirleriyle denetlemeğe ve gazeteci yalanlarna inanmamağa alışırlar. Bütün bunların üstünde, her şeyin açık olması dolayssıyla, iyi niyetin gelişeceğini ve yaşamsal sorunlar üzerinde iyiniyet sahibi insanların her zaman çoğunlukta olacaklarını kabul etmek uygun olur. Çünkü her zaman dünyanın yarısını ve bir zaman dünyanın hepsini aldatmak olanaklıdır. Ama bütün dünyayı her zaman aldatmak olànaksızdır. Deneyler göstermiştir ki, insanların herşeyi söylemelerini engellemeğe hiçbir zaman olanak yoktur. Ama ulusal eğitim ve büyük manevi güçlere karşı hükümetin uygun davranması yoluyla başkaldıncı düşüncelerin yayılmasına müsaade etmiyecek toplumsal bir ortam yaratılabilir. Ama her halde her şeyin söylenmesine müsaade etmek ve bunun karşısında söylenenlerin eyleme geçmesini bekliyerek önlem almakla yetinmek de anlamsızdur. Bütün halkın eyleme geçtiği gün, onları durduracak güç yoktur. Săğlık alanında bir koruyucu sağlık çalışması olduğu gibi, toplumsal bir 
koruyucu sağlık görevi de vardır. Her ikisi aynı ilkeye dayalıdır. Maddi mikropları yok etmeğe olanak bulunmadığı gibi, manevi mikropları da yoketmek olanaksızdır. Ama kişinin vücudunda bedensel bir sa.̆llk yaratılabileceği gibi, toplumsal yapıda da manevi bir sağlık yaratmak ve böylece bir direnç ortamı hazırlamak olanaklıdur.

\section{Gazeteler}

Türkiye Cumhuriyetinde gazete çıkarmak, kitap yayınlamak, basımevi açmak için uyulması gerekli yollar Basın Yasası ve Basımev. leri Yasasında saptanmıştır. Zararlı yayınlar ve kişilere saldırı durumunda yaplacak işlem de bu yasalarda ve Ceza Yasasında yazılidir.

$\mathrm{Bu}$ konuda bizce söylenecek sözler şöyle özetlenebilir: Basının genel yaşamda ve Cumhuriyetin ilerleme ve gelişmelerinde taşıdığı görevler yüksektir. Basının tam ve geniş özgürlüğü iyiliğe kullanması konusunun nazik olduğu belirtilmeğe değer. Her türlü yasal sinurlamalardan önce, bir kalem sahibi bilime, gereksinimlere vo kendi siyasal anlayışlarına olduğu kadar, yurttaşların haklarına ve ülkenin -her türlü özel düşüncelerin üstünde olan- yüksek yararlarna da dikkat ve saygı göstermek manevi zorunluluğundadır. $\mathrm{Bu}$ zorunluluktur ki genel düzeni sağllyabilir. Gerçi basın özgürlüğünden ileri gelecek kötülükleri ortadan kaldıracak etkin araç, asla geçmişte olduğu gibi basın özgürlüğünü bağlıyan bağlar değildir. Tersine, basın özgürlüğünden doğacak sakuncaları giderme aracı yine basın özgürlüğünün kendisidir.

\section{Dernek Kurma Özgürtḧğü ve 5. Öğretim Özgürlüğü}

Dernek, birçok kişi tarafından bilgilerini ya da emeklerini sürekli olarak birleştirmek amaciyla oluşturulan kuruldur.

Cocuk Esirgeme, Kızılay dernekleri, Türk Ocaklar, Kadınlar Birliği gibi. Kulüpler de dernekler türündedir.

Öğretim, bir kimsenin kendi bilimini başkalarına öğretmesidir. Buradaki öğretimden amaç, aile içinde yapllan öğretim ve öğrenim değildir; bir kurum açarak genel eğitimde bulunmaktır.

Dernek ve öğretim özgürlükleri, öteki birey özgürlüklerinden değişiktir. Çünkü bunlar, ortaklaşa bir etkinliğin sürekli olarak uygulanmasını gerektirir. Bu nedenle yalnız bireysel haklar gibi düşünülemezler. 


\section{Dernekter}

Dernekler bir yandan toplum bütünlügünü güçlendirir, ama bir yandan da kurulan dernekler devlet içinde başlıbaşına birer örgüt ve birer güç olacaklarından, devlet için tehlikeli de olabilirler. Bu nedenie dernek kurma, anayasamızda bireylerin doğal haklarından tanınmış olmakla birlikte, dernek kurma ayrıca bir yasayla sınırlanmıştır. Dernekler yasasına göre:

a) Dernek, kuruluşundan sonra, kesinlikle ve usulüne göre bükümete bildirilmek gerekir.

b) Yürürlükteki yasalara, genel ahlaka aykırı, yasal olmayan bir temele dayalı ya da devletin bağımsızlığını, hükümetin biçimini bozmak ve değişik ögeleri biribirlerinden ayırmak amaçlariyla dernekler kurulamaz.

c) Budun ve cinsiyet ölçü ve sanlarıyla siyasal dernekler kurulması yasaktır.

d) Dernek üyelerinin onsekiz yaşına girmiş bulunmaları koşuldur.

e) Gizli dernekler kurulması kesinlikle yasaktır.

f) Derneklerin toplandıklarn yerde her türlü silah yasaktır. Yalnız kulüplerde, güvenlik görevlilerinin bilgisi altında meç uygulamasına ve avcilığa özgü silahlardan gerekli olan sayıda bulunabilir.

\section{Öğretim}

Öğretime gelince, bu da çok önemli ve naziktir. Devlet yurttaşların ögrrenim ve eğitimleriyle çok ilgilidir. Bir kez ilk öğretimi zorunlu tutar ve genel olarak ögretim hükümetin gözetimi altında ve onun proğramları içinde olur. Çünkü öğretim özgürlüğü niteliği bakımından karışıtır. Bir yandan bireysel özgürlügün gereğidir, ama ortak örgüte dayanır. Onun için ögretimin yasayla özel bir düzenleme altına alınması gerekir. Anayasada buna ilişkin madde şudur: "Hükümetin gözetim ve denetimi altında ve yasa içinde her türlü öğretim özgürdür."

Yalnız Harp Okuluna kaynak olan askeri liseler, Milli Savunma Bakanlığına burakılmıştır.

\section{DUYURMA VE YAKINMA HAKKI}

"Türkler gerek kişiliklerine, gerek kamuya ilişkin olarak yasalara ve kurallara aykırı gördükleri konularda ilgili kuruluşa ve 
Türkiye Büyük Millet Meclisi'ne bireysel olarak ya da topluca duyuru ve yakunmada bulunabilirler. Kişisel olarak yapılan başvurunun sonucunun dilekçe sahibine yazll olarak bildirilmesi zorunludur."*

Bu yakınma hakkı, sözü edildiği gibi bir haksızlığa karşı yakınma niteliğinde olursa, bireysel hak olur. Ama yasalardan yakınma ve yasaların değiştirilmesine ilişkin öneri niteliğinde olursa, bu yön yurttaşın siyasal girişimi demek olur ki, bunun biçimi ve sınırı yasayla sunurlanmıştır.

"Yasa önermek hakkı, Meclis üyelerine ve Bakanlar Kurulu'na aittir."**

Bunun dışında siyasal amacını göstermek istiyen yurttaş, kitap yazarak ve basından yararlanarak isteğini yerine getirir. Kamuoyuna saygilı olan hükümetler ya da meclisler bunlarn gözönünde bulundurur.:

\section{Bireysel Hak ve Siyasial Hak}

Bireysel hak siyasal hak demek değildir. Bireysel haklara medeni haklar ya da kamu ya da topluluk hakları gibi adlar verenler olmuştur. Ad ne olursa olsun, bireysel haklar siyasal haklar dediğimiz şeyden başkadır.

Siyasal haklar, yurttaşların yönetime katılmalarını sağlıyan haklardır; bunun en açı ve belli örneği siyasal seçimdir.

Siyasal haklardan, ancak yasanin bu haklar kendilerine verdiği yurttaşlar yararlanabilir.

Siyasal haklar cins, yaş ve yetenek farkı olmaksızın ulusun her üyesine vẹilmemiştir."

Bireysel haklar ise ilke olarak yaşları ve yetenekleri ne olursa olsun, ulusu oluşturan her bireye aittir. Bu hakların da bir bölümü, gördüğümüz gibi, bir takım sınırlamalara bağımlıdır; bunun nedeni ikidir :

1. Bu haklar uygulanışlannda siyasal bir etkinlik oluşturabilirler; bu etkinlik hükümete dolaylı olarak katılmaya varır. Basın

\footnotetext{
* Anayasa Md. 82.

** Anayasa Md. 15.

** Anayasa Md. 10.
} 
özgürlüğü, dernek kurma özgürlüğü, toplantı yapma özgürlüğü ve hatta geleceğin yurttaşların yetiştiren öğretim özgürłüğü gibi.

2. Bireysel özgürlüğünü henüz edimsel olarak kullanmaya yeterli olmıanların korunması söz konusu olur. Örneğin çalışma özgürlüğü kimi durumlarda sınırlanır. Çocuklar ve kadinlar bakımından olduğu gibi.

\section{Özgürlüğ̈n Korunması ve Yaptırımlar}

Çağdaş anayasalarda, bireysel haklar ve yurttaşın siyasal hakları saptanmıştır. Ama bu hakların edimsel olarak kullanılması için onların nasıl kullanılacağını ve sinirlarını düzenliyen yasalar da gereklidir. Böyle olmazsa Anaýasa'da sağlanan haklar kullanılmaz birer 'verilmiş söz' olarak kalırlar. Bu nedenle haklarnn kullanılmasını düzenlemek çok zorunlu bir kuraldır.

Anayasa ve yasanın içerdiği hükümlerin uygulanışını düzenliyen yasalar, yurttaşların doğal ve siyasal hak ve özgürlüklerinin yaptırımlarıdır. Ama asıl yaptırım hükümettir. Yurttaş özgürlüğünü tanıyan, ona saygı gösteren, onun sağlanmasını ve korunmasını en birinci görev bilen siyasal yönetim ise, doğal olarak demokrasi ilkesine dayal olan cumhuriyettir. Eski dönemde özgürlüklerin korunması gibi bir sorun söz konusu değildi; çünkü özgürlük yoktu. 